\title{
REPRODUCTIVE HORMONE IN TRANSFUSION DEPENDENT BETA THALASSEMIA MAJOR PATIENTS.
}

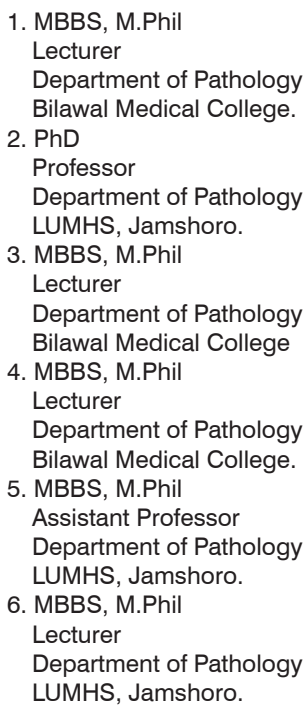

Correspondence Address: Dr. Sana Fatima Baloch Lecturer

Department of Pathology,

Bilawal Medical College

sana87@dr.com

Article received on: 10/05/2019

Accepted for publication: 26/08/2019

\begin{abstract}
Sana Fatima Baloch', Ikram Din Ujjan², Sadia Shahmeer ${ }^{3}$, Nazia Hafeez ${ }^{4}$, Kiran Amir ${ }^{5}$, Abdul Rehman ${ }^{6}$

ABSTRACT...Objective: To evaluate endocrine profile in transfusion dependent betathalassemia major patients. Study Design: Descriptive cross sectional study. Setting: Department of Pathology Liaquat University of Medical and Health Sciences, Jamshoro / Hyderabad and Thalassemia Centre Hyderabad. Period: 6 months from January 2018 to June 2018. Material \& Methods: Cases already diagnosed with $\beta$ - thalassemia major with recurrent blood transfusions (>20 transfusions or transfusion period over 2 years) both genders were included. All the patients went through routine laboratory checkups including Testosterone hormone, Luteinizing Hormone, and Follicle Stimulating Hormone. Data was recorded in preplanned proforma. Results: Overall 114 subjects were studied and their mean age was found to be $12.38 \pm 5.71$ years. Females remained in majority as $56.1 \%$. Mean of follicle stimulate hormone (FSH) and luteinizing hormone (LH) level were $4.60 \pm 4.88$ and $5.39 \pm 8.39$ respectively. Most of the patients, $35.1 \%$ had $>300$ of transfusion rate. Ferritin levels were significantly correlated with patients with history of transfusion rate $>300$; $p$-value 0.003 . Testosterone level's mean was considerably high among patients presented with transfusion rate of 201 to 300 and $>300$ transfusions; p-value 0.006 . Likewise, mean of FSH and LH level was as well significantly high among the female subjects with history of transfusion rate of 201 to 300 and $>300$ transfusions; P-Values 0.019 and 0.026 respectively. Conclusion: Frequent hypogonadism was noted among thalassemia patients. Very low level average of $\mathrm{FSH}, \mathrm{LH}$ and testosterone was seen.
\end{abstract}

Key words: Beta-thalassemia major, Endocrine Profile.

Article Citation: Baloch SF, Ujjan ID, Shahmeer S, Hafeez N, Amir K, Rehman A. Reproductive Hormone in Transfusion dependent ßeta thalassemia major patients. Professional Med J 2019; 26(12):2179-2183.

DOI: 10.29309/TPMJ/2019.26.12.3703

\section{INTRODUCTION}

Beta-thalassemia denotes a set of recessively heritable hemoglobin disorders detected by decreased formation of $\beta$-globin sequence. It is believed to be the commonest genetic disorder aglobally. ${ }^{1} \beta$-thalassemia is a recessively heritable autosomal hemoglobinopathy and is highly prevalent in Pakistani nation. ${ }^{2}$ Each year 4 to 9 thousand neonates with $\beta$-thalassemia ( $\beta$-thal) major are becoming the part of current burden of this disease. The carrier rate is 5.0\%- $8.0 \%$ in Pakistan and is noticed homogeneously distributed in all ethnic populations. ${ }^{3}$ The present cases of $\beta$-thalassemia-I carriers are around 240,000,000 globally. Each year around 100 thousand neonates enter this world with thalassemia. ${ }^{4}$ In Pakistan around 5 to 9 thousand neonates are born with $\beta$-thalassemia yearly, though no records are available. The projected carrier rate is $5.0 \%$ to $8.0 \%$, with 9800,000 carriers in the overall population of Pakistan. ${ }^{5}$ Even though blood transfusions are vital for anemia patients, chronic transfusions certainly result in iron overload, since human body in unable to actively eliminate excess iron. The increasing consequences of iron overload cause substantial mortality and morbidity, if remained intact. ${ }^{6}$ Excess iron is highly toxic to the body cells and can result in irreversible and serious organic destruction, such as hypogonadism, heart disease, diabetes, and cirrhosis. ${ }^{7}$ Many authors recounted a high rate of endocrine in patients of $\beta$-thalassemia major. ${ }^{8,9}$ Children, those have thalassemia, exhibit growth retardation in pre-pubertal, infantile, foetal 
and pubertal times.

Sexual immaturity remains a serious problem of acute thalassemia. Numerous studies in gonads-related and pituitary-gonadal functions have started primary gonadal dysfunction in case of gonadal iron accumulation. Secondary hypogonadism is caused by iron accumulation on pituitary gland's gonadotrophic cells as presented by poor response of $\mathrm{LH}$ and $\mathrm{FSH}$ to $\mathrm{GnRH}$ stimulation or a group of both secondary and primary hypogonadism. Some studies reported the incidence rate of failure of puberty commencement up to $50.0 \%$ and could even reach $100.0 \%$. Evidence suggest that individuals with further severe disorders have a higher rate of iron loading maybe due to high sensitivity to toxicity of free radicals. Iron toxicity on adipose tissues has also been shown to damage the formation of Leptin (a polypeptide hormone) and thus a delay in sexual maturation. ${ }^{10}$ Leptin is formed via adipose cells as a result of obgene expression and functions as a free signal to start puberty. Gross iron overload in pituitary, gonads and hypothalamus are ongoing yet with chelation therapy. Subjects with low gonadotropin have substantial insensitivity to gonadotropin hormones harmonizing with a pituitary and hypothalamic impairment. Delayed commencement of secondary amennorhoea, oligomenorrhoea, menarche, diminished testicular size (of 6.0-8.0 $\mathrm{ml}$ ) and size of breast at Tanner Stage-II or -III are frequent manifestations of considerably raised serum ferritin and iron levels. The total incidence was $72.0 \%$, with $45.0 \%$ incidence in boys and $39.0 \%$ in girls. Adequate data mainly on local level was not found in literature. Hence this study has been carried out to assess the reproductive hormone in patients of $\beta$-thalassemia major.

\section{MATERIAL AND METHODS}

This descriptive cross sectional study was held at Department of Pathology Liaquat University of Medical and Health Sciences, Jamshoro/ Hyderabad and Thalassemia Centre Hyderabad. Study duration was 6 months from January 2018 to June 2018. All the patients aged from 5 to 30 years and already diagnosed with $\beta$ - thalassemia major with recurrent blood transfusion dependent.
( $>20$ transfusions or transfusion period $>2$ years), both of the male and female genders were enrolled in this study. Subjects with congenital hypothyroidism goiter and those who were taking prior medications related to endocrine function and annular pancreas/pancreatic tumors were excluded from study. All the subjects went through routine laboratory investigations together with Testosterone hormone, Luteinizing Hormone, and Follicle Stimulating Hormone. In male subjects serum testosterone, and among females serum LH and FSH were carried out by taking $6 \mathrm{ml}$ of serum through standard sampling tubes and specimens were centrifuged for 10-15 minutes at 25 hundred round per minute (RPM) in HERAEUS LABOFUGE 400 (a thermostat scientific Machine). After centrifugation specimens were analyzed through Electrochemiluminescence immunoassay (ECLIA) achieved on Cobas e 6000 series (cobas e 601) or cobas e 411 analyzer by Roche Hitachi. All the data was collected on the proforma. Data was analyzed via SPSS version 16. Mean \pm standard deviation was computed for quantitative variables. Simple frequencies and percentages were calculated for categorical variables. Stratification in terms of gender, age and number of transfusion was carried out by chi square test and $p$-value $\leq 0.05$ was taken as significant.

\section{RESULTS}

Overall 114 subjects were studied and their mean age was found to be $12.38+5.71$ years with minimum and maximum age range of 5 and 35 years respectively. Females remained in majority $56.1 \%$ while males were $43.9 \%$. Table-l: Average of testosterone levels was assessed among 50 male subjects and its mean was found to be $1.92+3.57$, however this mean level was very low and this can possible be because of small age of most patients. 64 females were observed in terms of luteinizing hormone (LH) and follicle stimulate hormone (FSH). Mean of FSH and $\mathrm{LH}$ levels were found as $4.45+4.73$ and $4.30+6.60$ respectively. Table-II: Mean of $\mathrm{FSH}$ and $\mathrm{LH}$ levels were significantly high among the female subjects who had a history of 201 to 300 transfusion and >300 transfusions; p-values 0.019 and 0.026 respectively. This significant difference of $\mathrm{FSH}$ and 
LH levels could also be because of lower rate of transfusions among females due to the lower age. Table-III: Likewise mean of testosterone levels was as-well significantly high among the patients presented with transfusion rate of 201 to 300 and $>300$ transfusions; $p$-value 0.006 . This significant variance could also possibly be because of lower age of subjected who were presented with lower rate of transfusions. Table-IV:

\begin{tabular}{|l|c|c|}
\multicolumn{1}{|c|}{ Gender } & Frequency & Percent \\
\hline Female & 64 & 56.1 \\
\hline Male & 50 & 43.9 \\
\hline Total & 114 & 100.0 \\
\hline Age & \multicolumn{2}{|c|}{$12.38 \pm 5.71$} \\
\hline Mean+SD & \multicolumn{2}{|c|}{12.0} \\
\hline
\end{tabular}

Table-I. Patient distribution according to gender and age $n=114$

\begin{tabular}{|l|l|}
\hline \multicolumn{1}{|c|}{ Variables } & Mean \pm SD \\
\hline Testosterone level $n=50$ & $1.92 \pm 3.57$ \\
\hline FSH $n=64$ & $4.45 \pm 4.30$ \\
\hline LH $n=64$ & $4.73 \pm 6.60$ \\
\hline
\end{tabular}

Table-II. Mean of Testosterone in males and FSH and LH level in females $n=50$

\begin{tabular}{|l|c|c|}
\hline \multicolumn{1}{|c|}{ No. of transfusion } & Frequency & Percent \\
\hline$>300$ & 40 & 35.1 \\
\hline $201-300$ & 34 & 29.8 \\
\hline $101-200$ & 20 & 17.5 \\
\hline $1-100$ & 20 & 17.5 \\
\hline Total & 114 & 100.0 \\
\hline
\end{tabular}

Table-III. Patient distribution in terms of transfusion rates $n=114$

\begin{tabular}{|c|c|c|c|c|c|}
\hline \multirow[b]{2}{*}{ Variables } & \multicolumn{4}{|c|}{ No. of transfusion } & \multirow{2}{*}{$\begin{array}{c}\text { P- } \\
\text { Value }\end{array}$} \\
\hline & $>300$ & $\begin{array}{l}201- \\
300\end{array}$ & $\begin{array}{l}101- \\
200\end{array}$ & $<100$ & \\
\hline $\begin{array}{l}\text { LH level } \\
n=64\end{array}$ & $\begin{array}{l}2.11 \\
+ \\
3.40\end{array}$ & $\begin{array}{c}9.0 \\
\pm \\
0.38\end{array}$ & $\begin{array}{c}4.19 \\
+ \\
3.39\end{array}$ & $\begin{array}{c}7.18 \\
\pm \\
9.55\end{array}$ & 0.026 \\
\hline $\begin{array}{l}\text { FSH level } \\
n=64\end{array}$ & $\begin{array}{l}2.96 \\
+ \\
1.71\end{array}$ & $\begin{array}{c}1.24 \\
\pm \\
1.19\end{array}$ & $\begin{array}{c}4.58 \\
\pm \\
3.30\end{array}$ & $\begin{array}{l}6.45 \\
\pm \\
6.58\end{array}$ & 0.019 \\
\hline $\begin{array}{l}\text { Testosterone } \\
\text { level }\end{array}$ & $\begin{array}{l}0.84 \\
+ \\
1.94\end{array}$ & $\begin{array}{c}0.02 \\
\pm \\
0.03\end{array}$ & $\begin{array}{c}1.17 \\
\pm \\
2.79\end{array}$ & $\begin{array}{l}4.25 \\
\pm \\
2.79\end{array}$ & 0.006 \\
\hline
\end{tabular}

Table-IV. Association of LH And FSH with No: of Transfusions in Female Patients $n=64$

\section{DISCUSSION}

Beta thalassemia major is a recurrent hereditary hemoglobinopathy. Growth retardation and excessive iron load are the frequent secondary complications among thalassemia cases those underwent multiple-transfusions. Thus, close monitoring of iron burden with effective iron chelation is necessary in these subjects. Regular erythrocytes transfusions being essential for survival of these subjects lead them to unavoidable excessive iron load, which is expressed by raised levels of ferritin. Progressive accumulation of iron results in failure and dysfunction of major organs. Current study intended to assess the reproductive hormone in $\beta$-thalassemia major subjects. In this study patients' mean age was $12.38+5.71$ years with minimum and maximum range of 5 years and 30 years respectively. Females remained in the majority $56.1 \%$ in comparison to $43.9 \%$ males. Similar findings were reported by Karunaratna AM et $\mathrm{al}^{11}$ where out of 40 patients of $\beta$-thalassemia major, females were 22 (55\%) and males were 18 $(45 \%)$ with a mean age of $10.97 \pm 5.9$ years. In one more study by Sultan S et al ${ }^{12}$ out of 36 patients of $\beta$-thalassemia major males were 17 and females were 19 with a reported mean age of $12.56 \pm 5.9$ years. In consistent, Hashemi $A$ et $\mathrm{al}^{13}$ reported 34 males and 31 females out of 65 subjects. Consistent findings were reported in terms of age (mean age 10.30 years), with thalassemia major.

In present study total average of testosterone levels was lower which was observed among 50 male subjects with mean of $2.95+4.12$ for testosterone levels. Mean of testosterone levels was considerably high among subject who were presented with transfusion rates of 201 to 300 and $>300$; p-value 0.006 , this significant variance could possibly be because of lower aged patients presenting with lower rates of transfusions. Likewise mean of $\mathrm{FSH}$ and $\mathrm{LH}$ levels was also considerably high among the female subjects who had a history of 201 to 300 transfusions and $>300$ transfusions; p-value 0.019 and 0.026 respectively, this significant variance could also be justified by the lower rates of transfusions as the females had lower age. In contrast Vahidi $\mathrm{AA}$, et $\mathrm{al}^{14}$ documented mean testosterone levels significantly depressed among thalassemic 
males than controls ( $p$ value 0.003) and Mean levels of $\mathrm{LH}$ and FSH were considerably lower among subject with $\beta$-thalassemia major $(p<$ 0.001). In subjects with thalassemia major dwelling in underdeveloped nations, endocrine complications can possibly be frequent as a result of suboptimal iron chelation. In an earlier prospective study of Gulati et al ${ }^{15}$ from Indian, majority of the thalassemic young adults or adolescents had hypogonadism. In one more study of Kiumarsi A et $\mathrm{al}^{16}$ the mean levels of $\mathrm{FSH}$, $\mathrm{LH}$ and Testosterone were reported as $3.7 \mathrm{mIU} /$ $\mathrm{ml}, 4.6 \mathrm{mlU} / \mathrm{ml}$, and $4.8 \mathrm{ng} / \mathrm{dl}$ respectively. A few other studies as well reported that delayed puberty and hypogonadism are the commonest endocrinopathy among thalassaemic subjects $(40-91 \%){ }^{17,18}$

\section{CONCLUSION}

It was concluded that hypogonadism and hypothyroidism were most common. Very low level average of testosterone, $\mathrm{FSH}$ and $\mathrm{LH}$ were observed. More recent research is required on correlation of endocrine profile and ferritin level. Copyright@ 26 Aug, 2019.

\section{REFERENCES}

1. Ansari SH, Shamsi TS, Ashraf M, Bohray M, Farzana T, Khan MT, Perveen K, Erum S, Ansari I, Nadeem M, Ahmed M. Molecular epidemiology of $\beta$-thalassemia in Pakistan: far reaching implications. International journal of molecular epidemiology and genetics. 2011;2(4):403.

2. S. Sultan, S. M. Irfan, R. Zeeshan, J. Kaker, andA. Kidwai, "Zinc status and its correlation with basic parameters in transfusion dependent thalassemic patients: Pakistani perspective," Iranian Journal of Blood and Cancer, 2014; 6; 3;113-18.

3. Ansari SH, Shamsi TS, Ashraf M, Farzana T, Bohray $M$, Perveen $K$, et al. Molecular epidemiology of $\beta$-thalassemia in Pakistan: Far reaching implications. Indian J Hum Genet. 2012 May-Aug;18(2):193-97

4. Sadia Sultan, Syed Mohammed Irfan, and Syed Ijlal Ahmed. Biochemical Markers of Bone Turnover in Patients with $\beta$-Thalassemia Major: A Single Center Study from SouthernPakistan. Advances in Hematology Volume 2016 (2016), Article ID 5437609, 5 pages
5. Kanwal S, Bukhari S, Perveen S. Molecular genetics and prenatal diagnosis of beta thalassemia to control transfusion dependent births in carrier Pakistani couples. J Pak Med Assoc. 2017 Jul 1; 67:1030-4.

6. Cappellini MD. Exjade(R) (deferasirox, ICL670) in the treatment of chronic iron overload associated with blood transfusion. Ther Clin Risk Manag. 2007; 3:2919.

7. Melchiori L, Gardenghi S, Rivella S. Beta-Thalassemia: HiJAKing Ineffective Erythropoiesis and Iron Overload. Adv Hematol. 2010;2010:938640-938640

8. Majeed MS. Evaluation of some Biochemical and Endocrine Profiles in transfusion-dependent Iraqi major $\beta$-thalassemia patients. Iraqi Journal of Science. 2017; 58(2A):639-45.

9. Canale VC, Steinherz P, New M, Erlandson M. Endocrine function in thalassemia major [Abstract]. Ann NY Acad Sci 1974; 232: 333-45.

10. G. R. Moshtaghi-Kashanian and F. Razavi, "Ghrelin and Leptin Levels in Relation to Puberty and Reproductive Function in Patients with Beta-Thalassemia," Hormones (Athens), Vol. 8, 2009, pp. 207-213.

11. Karunaratna AM, Ranasingha JS, Mudiyanse RM. Iron overload in beta thalassemia major patients. Int $\mathrm{J}$ Blood Transfus Immunohematol. 2017; 7:33-40.

12. Sultan S, Irfan SM, Ahmed SI. Biochemical Markers of Bone Turnover in Patients with $\beta$-Thalassemia Major: A Single Center Study from Southern Pakistan. Advances in hematology. 2016; 2016.

13. Hashemi A, Hashemian Z, Ordooei M, Amanat M, Purshamsi F, Ghasemi N, Eslami Z. Endocrine Dysfunctions in Iron Overload in Patients with Major Thalassemia. Iranian Journal of Pediatric Hematology \& Oncology. 2012 Jun 1; 2(2).

14. Vahidi AA, Torabinejad MH, Ahmadi A, FARAHMANDINIA Z, KIANI MOGHADDAM G, Meghdadi B. A crosssectional controlled study of gonadal function and pubertal development in thalassemia major. Medical Journal of the Islamic Republic of Iran (MJIRI). 2003 May15; 17(1):5-10.

15. Gulati R, Bhatia Y, Agarwal SS: Early onset of endocrine abnormalities in beta-thalassemia major in a developing country. J Pediatr Endocrinol Metab 2000;13(6):651-656.

16. Kiumarsi A, Ansari S, Azarkeivan A, Mahdi Allameh M, Razzaghiazar M. Do Iron Chelators Affect Fertility in Thalassemic Men. Hem Diseas Therapies. 2017. 
17. Taher AT, Musallam KM, Karimi M, El-Beshlawy A, Belhoul $\mathrm{K}$, et al. Overview on practices in thalassemia intermedia management aiming for lowering complication rates across a region of endemicity: the optimal care study. Blood 2010;115: 1886-1892.
18. Vogiatzi MG, MacKlin EA, Trachtenberg FL, Fung EB, Cheung $A M$, et al. Differences in the prevalence of growth, endocrine and vitamin D abnormalities among the various thalassaemia syndromes in North America. British Journal of Haematology 2009;146: 546-556.

\begin{tabular}{|c|c|c|c|}
\hline \multicolumn{4}{|c|}{ AUTHORSHIP AND CONTRIBUTION DECLARATION } \\
\hline Sr. \# & Author(s) Full Name & Contribution to the paper & Author(s) Signature \\
\hline 1 & $\begin{array}{l}\text { Sana Fatima Baloch } \\
\text { Ikram Din Ujian }\end{array}$ & $\begin{array}{l}\text { Data collection, and } \\
\text { manuscript writing. } \\
\text { Manuscript review. }\end{array}$ & Sama Fatima \\
\hline 3 & Sadia Shahmeer & $\begin{array}{l}\text { Data analysis and manuscript } \\
\text { writing. }\end{array}$ & Sadia \\
\hline 4 & Nazia Hafeez & $\begin{array}{l}\text { Participation in data } \\
\text { collection. }\end{array}$ & Yazia Yaffeez \\
\hline 5 & Kiran Amir & Participation writing and & Kiran Amir \\
\hline 6 & Abdul Rehman & Participation in data analysis. & Aboul Rehwan \\
\hline
\end{tabular}

